\title{
Research on Establishment of Teaching Quality Assurance System in Independent Colleges
}

\author{
Hua Tao \\ Jincheng College \\ Nanjing University of Aeronautics and Astronautics \\ Nanjing, Jiangsu, China 211156
}

\begin{abstract}
In recent years, non-government funded education in our country has achieved rapid development. Independent college is an important force in higher education of our country, so a growing number of scholars pay close attention to teaching quality assurance of independent colleges. This article attaches importance to researching problems of independent colleges in teaching quality monitoring and puts forward about how to establish teaching quality monitoring system of independent colleges, in order to provide some advice for development of independent colleges of our country.
\end{abstract} system

Keywords-independent college; teaching quality; assurance

\section{INTRODUCTION}

In recent years, non-government funded education in our country has achieved rapid development. Independent College is an important force of higher education of our country. It has become an important part and new point of growth of higher education as well as assistor for higher education development. As a new model and mechanism, independent college is the supplement of quantity of high quality undergraduate education and also the supplement of undergraduate education type. Because of problems of its mechanism, people are more concerned about its teaching quality. Teaching quality is the foundation of survival of independent college. It decides the quality of talent training. Monitoring of teaching quality is the core content of teaching management in independent colleges. Effective monitoring is an important assurance for independent colleges to stabilize and improve teaching quality. Therefore, urgent and realistic problems such as how to guarantee teaching quality of independent college, how to guarantee students cultivated by them can adapt to economic development and how to improve teaching quality are faced by non-governmental colleges. Independent colleges must establish feasible teaching quality monitoring system and guarantee quality level of teaching. So this article pays attention to researching problems existed in independent colleges in teaching quality monitoring and puts forward how to establish teaching quality monitoring system of independent college, in order to provide some advice for development of independent colleges of our country.

\section{PRoblems Existed In TeAching Quality ASSURANCE SYSTEM OF INDEPENDENT COLLEGE}

\section{A. Not Yet Establish Mature Teaching Staff}

Independent colleges often enroll students in the third batch of undergraduate colleges, so people have certain bias towards students who are enrolled in independent colleges. It is the main problem faced by them about how to improve core competitiveness and enhance social identity. Independent colleges can have a foothold in market competition only through ensuring teaching quality and cultivating excellent talents urgently needed by the society. Excellent teaching staff is the key to guarantee teaching quality. At present, teaching staff in independent colleges has the following problems.

- Looking from composition of teachers in independent colleges, independent colleges employ full-time teachers and external teachers both from parent universities or other schools. It is an important way to improve teaching quality of independent colleges through making use of teaching staff of parent universities. But teachers in parent universities have workload. Except for teaching tasks of independent colleges, they also take on teaching and research work in parent universities. On one hand, they haven't enough energy so the teaching quality is not so good; on the other hand, because there is certain gap between students in parent universities and students in independent colleges on learning ability, these teachers often cannot treat them equally without discrimination, which may hurt self-confidence of students in independent colleges and influence their learning enthusiasm.

- The age structure of teachers is unreasonable and presents the situation of "less in the middle and more in both ends". Independent colleges have a late start without teachers with rich experience. Most are young teachers who just graduate from schools. They know little about students and lack the ability to control the class. Besides, they are not familiar with objective law of teaching in classroom and have few teaching experience. It has a great influence on improving teaching quality. Aged teachers are easy to follow the beaten track. Although they have richer experience than 
young teachers, their innovation ability is obviously inadequate.

- Teaching staff in independent colleges isn't stable. With the development of economy and increase of price level, a great many teachers first consider their treatment and development. Because of school-running system, non-governmental colleges put inadequate investment in teachers' treatment, which is the main reason of talent flow. For young teachers, they will choose non-governmental colleges when they just graduate from schools because of less alternatives. After they are employed by independent colleges, they just regard it as a springboard, so they are unwilling to spend too much time in researching how to teach. They put more energy in how to improve their academic degrees and diplomas, in order to leave once there is a choice and they pay no attention to improvement of teaching quality. On the other hand, external teachers employed by independent colleges also occupy a large proportion. External teachers in some independent colleges take on most of the teaching tasks. However, these part-time teachers employed are also teachers of other universities who have to undertake certain tasks of teaching and scientific research in regular institutions of higher learning. It belongs to their extra teaching tasks to teach in independent colleges. It means they have to reduce rest time correspondingly. Because it is difficult to guarantee teaching time and energy of these teachers, it cannot guarantee teaching quality, either. In addition, when conflicts occur on both sides, external teachers firstly consider sacrificing interests of independent colleges, so they mediate classes. The teaching order is disorganized and it is hard to improve teaching quality.

\section{B. Major Setup Is Inaccurate}

Major is the basic unit for independent colleges to cultivate talents. At present, major setup in independent colleges mainly has the following problems: (1) they copy major setup and related teaching plans of parent universities. Because parent universities cultivate research-based undergraduates while the purpose of talent training in independent colleges is applied talents, copying major setup and teaching plans of parent universities is not suitable for development of independent colleges and restricts its development space. (2) it cannot highlight characteristics of independent colleges on major setup. In early development, they copy some majors of parent universities, but in the process of actual operation, teaching infrastructure and teaching staff cannot keep up with it, which lead to the situation that it is difficult to improve teaching quality. (3) Independent colleges mainly focus on making profits. In order to save cost, when setting up majors, they often put more energy in considering school running cost. It leads to the fact that students cultivated by them cannot meet the requirements of society, and then the improvement of teaching quality is out of the question.

\section{The Monitoring Scope of Teaching Quality Is Narrow}

According to investigation and survey, in terms of teaching quality monitoring, independent colleges mainly focus on classroom teaching activities; they pay inadequate attention to monitoring other factors that influence teaching quality, such as students' learning situation after class, after-class tutoring of teachers and logistics service of school. The careless omission of any link will influence the improvement of teaching quality. It is obvious that the monitoring of teachers in independent colleges is single. Because of particularity of independent colleges and unstable teaching staff, the more serious the teaching management in school, the looser the teaching staff will be. At present, monitoring of teachers in independent colleges is mainly carried out through marking of students and supervision and examination with small monitoring scope, which greatly hinder the improvement of teaching quality. Moreover, the purpose of talent training in independent colleges is to cultivate applied talents, but independent colleges attach less importance to monitoring practical link of students. Because of restriction of time and space, many practical links cannot be monitored, so these links exist in name only. All of them impede the assurance of teaching quality.

\section{Teaching Management System Is not in Place}

Because independent colleges have a late start and institutional improvement in teaching management is imperfect, many independent colleges imitate or copy teaching system of parent universities. Because there is an essential distinction between independent colleges and parent universities in talent cultivation, the implementation effect of copying teaching management system of parent universities is poor. It cannot fully exert its efficiency. It is very difficult to arouse teachers' teaching enthusiasm and students' learning initiative without appropriate teaching management system, so it cannot guarantee the level of teaching quality.

\section{E. Teaching Management Teaching Is not in Place}

Monitoring of teaching quality in independent colleges is mainly carried out by personnel of teaching affair administration and student management and external teaching supervisor, so monitoring of teaching quality has close relationship with their abilities. Independent colleges have late start. Employers of it are young in general. Most of them are students who just graduate from schools or people who change profession. They lack experience in teaching quality monitoring. It is difficult for them to monitor because they are not familiar with teaching or cannot manage carefully. External teaching supervisors cannot play a due role because of system in independent colleges. Therefore, the process to strengthen teaching quality monitoring is the process that teaching management personnel need to execute strictly, also the process to improve professional proficiency as well as the process of the growth of educational administrative staff. It will certainly influence the construction course of quality monitoring system without excellent teaching affairs management staff. 


\section{F. The Monitoring of Parent Universities Is not in Place}

Many independent colleges are built through cooperation between parent universities and social enterprises. When establishing independent colleges, parent universities pay more attention to the interests, so they cannot do well in teaching instruction. In addition, they don't actively offer help and instruction on major setup, allocation of resources of laboratory and talent training programs. Parent universities hardly truly participate in teaching management of independent colleges, mainly providing some schemes and rules and regulations, which are not suitable for objective of talents training of independent colleges.

\section{ESTABLISHMENT OF TEACHING QUALITY ASSURANCE SYSTEM OF INDEPENDENT COLLEGES}

\section{A. Enlarge Talent Construction and Intensify Teaching Staff}

First, reasonably introduce and improve structure of teaching staff

Introducing talents shall base on actual requirements. When introducing talents, it is necessary to focus on considering structure of teaching staff at present, introduce middle-aged teachers with rich practical experience and higher teaching level and reduce the proportion of newly graduated students, practically improve quality of teachers introduced and master teaching quality from the source. They can adopt special incentive measures to introduce and cultivate highlevel professional leading talents, introduce more talents with title of a senior professional post, in order to build teaching staff with solid basic skills.

Secondly, pay attention to training of teachers and improve teaching level.

Independent colleges have a late start. There are many young teachers and teachers with primary title, while the enrollment scale of independent colleges is great and the staffstudent ratio loses balance seriously. Teaching load of young teachers is very big. They often give classes mechanically, unable to improve teaching quality. Young teachers spend most time in teaching, so teaching work of young teachers is very heavy, while the time spent by them in teaching and scientific research is less, which strike enthusiasm of teachers to work and make them have inadequate time and space to specialize in academic research and improve professional skill. It is adverse for integrated development of teachers. Besides, in the long run, it also has bad influence on teaching staff construction in school. Therefore, they shall pay attention to training and cultivation of teaching staff, create the atmosphere of respecting teachers and their teaching as well as attaching importance to talent training, integrate training of teachers in purpose of team construction and mechanism for selection competition and improve teaching level and scientific research ability of existing teachers. What's more, they can encourage teachers to get professional qualification certificate of related majors, provide more opportunity for teachers to exercise outside school to unceasingly improve their practical ability, accelerate construction of "double-qualified" teaching staff, in order to lay solid foundation for independent colleges to cultivate applied talents.

\section{B. Strengthen System Construction and Improve Quality Standard}

There are great differences between independent colleges and regular higher educational institutions in teachers, the quality of students and objective of talents training, so independent colleges cannot copy various rule and regulations of parent universities but combine characteristics of independent colleges to build feasible rules and regulations that conform to their development requirements. Intensify execution of rules and regulations, ensure true implementation of it and truly embody management features of independent colleges. In order to ensure normal operation of teaching, it is necessary to formulate practical quality standard of links such as teaching program, teaching schedule, examination assignment, experiment teaching syllabus, teaching program of practical training and proposition of graduation thesis (design) and strictly monitor according to quality standard.

\section{Enrich Monitoring Contents and Realize Management of the Whole Process}

The contents of construction of teaching quality monitoring system shall be comprehensive and carried out in the whole process: Except for monitoring students' learning, they shall also establish proper systems of skill assessment and quality assessment and strengthen the evaluation and feedback of students' integrated quality; further monitor teachers' teaching through teaching inspection, visiting class and students' evaluation on teaching and checking attendance rate of students, reforming ways and methods of examination and supervision of learning style. Strengthen quality monitoring of theory teaching, carry out special evaluation on experiment, internship, practical training and graduation thesis (design), and intensify monitoring of practical links; carry out real time monitoring of teaching current situation of teachers and students, establish tracking system for graduates, implement timely feedback of social effect of teaching quality, in order to further reform teaching and management methods and improve the quality of talent training.

\section{Effectively Guarantee Supervisory Role of Parent Universities}

National guidance points out applicants of independent colleges shall be responsible for teaching and management of independent colleges and guarantee its quality. Applicants must give full play to their advantages in intelligence and resources of talents and effectively strengthen construction of teaching body and management team of independent colleges, build and continuously improve system to monitor and evaluate teaching level of independent colleges". Therefore, as applicants for independent colleges, parent universities have compelling obligation on teaching quality of independent colleges and must strengthen instruction and supervision of teaching and management. Because independent colleges have short time of running school and lack school running experience, when determining school-running orientation, formulating development planning and carrying out special construction, parent universities must give instruction, meanwhile select and send teachers with rich experience to hold related posts of teaching management in independent 
colleges and lead education and teaching of work of independent colleges, besides, take performance of these people in independent colleges as important index of assessment.

\section{E. Effectively Make Use of the Effect of Market Feedback}

The school-running mechanism of independent colleges is that enterprises participate in running it. Compared with regular institutions of higher learning, it is closer to market. The school-running orientation of it is to cultivate applied talents, who are urgently needed by the society, so independent colleges shall pay more attention to feedback effect of market for talents. Specifically speaking, it includes: before setting up majors, they shall make adequate market survey and determine majors set up by them can cultivate talents needed by the market, then formulate and revise talent cultivating program with purpose and direction. Secondly, independent colleges shall intensify cooperation between school and enterprise and make efforts to cooperate with enterprises to create more opportunity of internship for teachers and students and improve their practical ability. Finally, implementing tracking system for graduates is the most important means to effectively make use of market to guarantee teaching quality of independent colleges. They can also set up special investigation team and regularly carry out follow-up survey in work unit of graduates to know about whether students' knowledge, ability and quality structure conform to market requirements, and then find problems and deficiencies existed in education and teaching, in order to promote independent colleges to scientifically adjust ways and methods of talent training and unceasingly improve teaching quality.

\section{REFERENCES}

[1] Xu Chao. Investigation and Survey on Characteristic Specialty Construction of Independent College of Private Higher Learning Institution [J], Education and Teaching Research, 2014, 26(1): 107-107

[2] Que Mingkun. Regional Distribution Phenomenon of Independent College Transformation in Our Country, Attribution and Countermeasures [J], Exploring Education Development, 2015(7):11-17. Shao Jin. Exploration and Analysis on Ways of Reform of Talents Training Mode in Independent College under New Normal of Higher Education [j], Jiangsu Higher Education, 2015(6): 91-93

[3] Yu Guanghui. Analysis on Neo-institutional Economics of Transformation Tendency of Independent College-on the Basis of Investigation of Three Cases [J], Exploring Education Development, 2015(5): 41-48

[4] Que Mingkun, Gan Dean. Five Years of Transitional Period of Independent College: Effect of Reform and Suggestions [J], Chinese Higher Education, 2015(24):31-34

[5] Kang Xiangang. Study on Talent Training of Differential Undergraduate Education of Independent College [J], Hubei Social Sciences, 2014(9)

[6] Huang Huaxian, Liu Chuan. Study on Important Links of Practical Education Work System of Independent College [J], Shandong Social Science, 2015(S2)

[7] Tang Jianmin, Yu Lin, Huang Lanlan. Research on Independent College Development Strategy of Cooperation Model between University and Enterprise [J], Higher Education Exploration, 2015(3): 78-81 